\title{
Mathematical modeling of folate-related processes in human placenta
}

\author{
V. A. Dotsenko, M. Yu. Obolenskaya \\ Institute of Molecular Biology and Genetics, NAS of Ukraine \\ 150, Akademika Zabolotnoho Str., Kyiv, Ukraine, 03680 \\ dotsdon@gmail.com
}

\begin{abstract}
Aim. Description the folate-related processes in the human placenta using the stoichiometric model and investigation the system's behavior under various conditions. Methods. The model is based on the stoichiometry of the reactions of the folate-related processes at steady state conditions and constructed using CellNetAnalyzer. Behavior of the system is described by elementary flux modes and control-effective fluxes depending on the activity of methylenetetrahydrofolate reductase and methionine synthase and input methionine flux. Results. Change in methylenetetrahydrofolate reductase activity causes a decrease in fluxes through the main routes of homocysteine elimination and increases the need for 5-methyltetrahydrofolate. Methionine synthase inactivation reduces 5-methyltetrahydrofolate consumption and increases the flux through the taurine syn-thesis. Lack of methionine leads to increased 5-methyltetrahydrofolate consumption, reduced homocysteine concentration and reduces the fluxes through the methionine cycle. Conclusions. Analysis of model functioning has shown the compliance of system's functioning changes with the clinic parameters. There is evidence that the homocysteine level as a marker offolate-related processes functioning of is not sufficient to justify the therapy.
\end{abstract}

Keywords: folate-related processes, stoichiometric model, elementary flux mode, control-effective fluxes.

Introduction. The problem of pregnancy failure is the issue of utmost significance. For instance, according to some data the frequency of complications in Ukraine is up to $60 \%$ or even $90 \%$ [1]. The threatened miscarriage is a complication of about $40 \%$ of pregnancies, the early termination of pregnancy is remarkable for 20-25 $\%$, and the preeclampsia is present in $10 \%$ of pregnancies [2]. The pathogenesis of a number of obstetric complications is yet to be defined in details, and the contribution of a genetic component into their development is insufficiently described in many cases. At present, barrenness and miscarriage are considered to be the results of a common action of the genetic and environment factors [3].

The research, described in this article, was based on two propositions. According to the first one a vital role in the pathogenesis of diseases is attributed to the placental metabolism [4], as the placenta is not only transporting nutrients and metabolism products from the fe-

(C) Institute of Molecular Biology and Genetics, NAS of Ukraine, 2014 tus to the mother, but is also actively metabolizing them. The placenta is a final barrier between the mother and the fetus, and placental metabolism disorder is the main factor of many pregnancy failures. According to the second proposition a vital role in the functioning of the placenta cells and the developing cells is attributed to the folate-dependent processes (FDP) [3]. Therefore, women are recommended to use the folic acid prior to the conception and especially in the first three months of pregnancy in order to prevent any pregnancy complications, in particular, the fetal neural tube defects.

The large-scale experimental research on the interrelations between the structure, function and regulation in large metabolic networks is still a complicated and costconsuming endeavor. The systems biology is solving this issue, combining the results of different experimental approaches and bioinformatics methods, in particular, modeling. One of these approaches is a structureoriented analysis, which requires the knowledge of network topology and the stoichiometry of biochemical re- 
actions, commonly known from the classic chemistry. They are used to build a stoichiometry model, describing the distribution of stationary metabolic fluxes (the metabolic flux is the rate of transformation of metabolites) in the metabolic pathway (the metabolic pathway is the sequence of chemical transformations of a certain substance) in different conditions, but it does not take into consideration the regulation, implemented in it.

The term «folate-dependent processes» is used to determine a group of biochemical reactions, in which the derivatives of folic acid, folates, are cofactors. The center of FDP is formed by two related cycles - folate and methionine cycles $[5,6]$. FDPs in liver have been studied the most extensively [7]. The folate cycle is represented by the derivatives of the folic acid with different degrees of oxidation. The main functions of folates are the transfer of one-carbon units in the biosynthesis reactions of nucleobases and the metabolism of amino acids as well as the transfer of a methyl group into the methionine cycle. All the methylation processes in the cell are related to the transformation of components in the methionine cycle, in particular, these are DNA methylation, the synthesis of amino acids - methionine and cysteine, and indirectly - the synthesis of glutathione and taurine. The most active FDPs are in the cytosol, less active ones - in mitochondria and nucleus [8].

A special role in the FDP system is attributed to the enzymes 5,10-methylenetetrahydrofolate reductase (MTHFR, EC 1.5.1.20), methionine synthase (MS, EC 2.1.1.13), as well as the introduction of methionine (Met) into the system. MTHFR - is a NADP-dependent enzyme, catalyzing the transformation of 5,10-methylenetetrahydrofolate $\left(5,10-\mathrm{CH}_{2}-\mathrm{THF}\right)$ into 5-methyltetrahydrofolate (5MTHF). The latter is a donor of the methyl group in the reaction of homocysteine (Hcy) methylation, resulting in the formation of Met with MS involved. It is known that the decrease in the enzymatic activity of the abovementioned enzymes due to mutations or the deficiency of group B vitamins, which are cofactors, as well as considerable fluctuations in the Met input lead to the significant disorders in the fetal development at the early stages of embryogenesis and even to the fetal death [9].

Taking the aforesaid into consideration, this work was aimed at the elaboration of a stoichiometry model of the FDP in human placenta, the simulation of the de- crease in the activity of the enzymes MTHFR, MS and the Met input and the analysis of the behavior of the system in these conditions.

Materials and methods. The mathematical description and the analysis of metabolic fluxes involved the Flux Balance Analysis (FBA) which is based on the assumption of the balance of metabolites and the linear programming.

The elaboration of the stoichiometry model and the conducted calculations included the following stages:

The mathematical description of folate-dependent processes. The mat hematical model of the process, composed of $n$ reactions, is a system of differential equations $\frac{d S_{n}}{d t}$ describing the dynamics of the metabolite concentration $(S)$. FBA is used for systems in a steady state, when $\frac{d S_{n}}{d t}=0$.

Therefore, the system of differential equations transforms into the system of algebraic equations, which may be presented in the form of a matrix [10].

The elaboration of a stoichiometry matrix based on the system of algebraic equations. The stoichiometry matrix is the matrix $m \cdot q$, where each element $n_{i j}$ is a stoichiometric coefficient, related to the metabolite $i$ in the reaction $j$ with the corresponding sign: a negative sign for the metabolite consumption, a positive sign - for its formation; $q$-reactions (matrix columns); $m$ - metabolites (matrix rows) [11]. The matrix was created in Cell NetAnalyser software 6.2.

The calculation of elementary modes (elementary flux modes, EFM) based on the stoichiometry matrix. EFM is a directed pathway, including the minimal and unique set of steady-state reactions [10]. The removal of any enzyme or any reaction from EFM leads to the termination of mode functioning. In mathematical terms, the set of EFM is a set of independent basic vectors, corresponding to the following conditions: a stoichiometry matrix $=0, i . e$. the vector is determined in a steady state; there is no other non zero vector to correspond to these restrictions and to involve the same set of reactions [11]. The number of EFM was calculated using CellNet Analyzer 6.2 software. The defined frequency of the participation of each reaction in different EFM testifies to the significance of the reaction and it's enzyme in the functioning of the system. 
The calculation of control-effective fluxes. The significance of each reaction for the efficient and flexible work of the whole metabolic system was determined using the control-effective fluxes (CEF) via this reaction in different EFM [12]. The analysis started with the assignment of the efficiency value to each EFM $\left(\varepsilon_{j, \text { CELLOBJ }}\right)$.

$$
\varepsilon_{j, C E L L O B J}=\frac{r_{C E L L O B J}^{j}}{\sum_{i} r_{i}^{j}},
$$

where $r_{C E L L O B J}^{j}$ is the objective function of the system; $\sum_{i} r_{i}^{j}$ - the sum of participation coefficients of each reaction in a certain EFM; $j$ - EFM index; $i$ - the index of a flux via a specific reaction in a given EFM [13].

Then CEF $\left(v_{i}\right)$ was defined for a certain reaction $\left(r_{j}^{i}\right)$ as an average flux via this reaction in all EFM, where the flux in each mode is balanced relative to its efficiency [13].

$$
\mathrm{v}_{i}=\sum_{\text {CELLOBJ }} \frac{1}{r_{\text {CELLOBJ }}^{\max }} \frac{\sum_{j} \varepsilon_{j, \text { CELLOBJ }}\left|r_{i}^{j}\right|}{\sum_{j} \varepsilon_{j, \text { CELLOBJ }}},
$$

where $r_{C E L L O B J}^{\max }$ is the maximal participation coefficient in EFM for reactions, involved in the objective functions of the cell; $\sum_{j} \varepsilon_{j, \text { CELLOBJ }}\left|r_{i}^{j}\right|$ is the sum of the products of participation coefficients for a certain reaction for all EFM and the corresponding calculated values of efficiency; $\sum_{j} \varepsilon_{j, \text { CELLOBJ }}$ is the total value of efficiency of all the modes.

To determine the behavior of the whole metabolic system in the conditions of deficiency of any enzyme, the participation coefficients for reactions in EFM, involving a deficiency enzyme, were multiplied by the constant $d_{j}$, which reflects the degree of the enzyme inactivation and takes the value from 1 to 0 . The efficiency values of these modes were also multiplied by $d_{j}$. The code for calculations was written in WolframMatematica software 7.0. The example of calculations is presented in Addendum 1.

Results and discussion. The first attempts to create a stoichiometry model of the FDP metabolic network for placenta on the basis of general data and the specificities of the relative genes expression in human placenta [14] were made in the work [15]. In this work the scheme of the metabolic network was extended, in particu- lar, we added the reactions of transformation of the glutamic acid as well as the reactions of input and output of metabolites [16] (Fig. 1).

The stoichiometry model is composed of 42 reactions, including the following: 4 reactions of the methionine cycle, 9 reactions of the tetrahydrofolate cycle, 2 transsulfuration reactions, 2 reactions of the glutathione synthesis, 3 reactions of the taurine synthesis, 2 reactions of the glutamic acid transformation and 20 reactions of the input and output of metabolites (Addendum 2).

Elementary flux modes. Fifty-three EFMs were calculated and isolated for FDP model in the cytosol of placental cells (Addendum 3). All the modes are irreversible. Most EFMs involve the participation of the following: the input flux Ser (37 EFM), the enzyme SHMT (33 EFM), the output flux GSH (29 EFM), the reaction of glutathione synthesis (28 EFM). Serine is used in the SHMT and CBS reactions for the synthesis of folates and Hcy transsulfuration. Glutathione is important to maintain the redox status of cells and to detoxify xenobiotics [17].

Other modes are responsible for the production of taurine, aminoacids (Met, Gly, Ser, Hcy), dTMP, 5MT $\mathrm{HF}$ and the methylation processes. There are also seven modes, wherein the metabolites are not synthesized. These are futile cycles, which occur when two metabolic pathways run simultaneously in opposite directions, use each other's products and, as a result, do not have other products, other than energy dissipation in the form of heat and transport of some metabolites through the placenta.

The EFM analysis demonstrates that there are no indispensable enzymes in the created metabolic network, i. e. the ones to take part in all the EFMs. This is the evidence to the network flexibility.

$C E F$ for the initial state. Seven most frequent reactions in all the EFMs and thus the most significant reactions for the functioning of the system were selected as the objective functions: Ser_in, SHMT, GSH_out, CBS, MTHFR, DNMT, TS (Addendum 4).

The highest value of the control-effective flux is for the serine input flux Ser_in, which is used in the synthesis of cystathionine and is a donor of $\mathrm{CH}_{2}$ group in the $5,10-\mathrm{CH}_{2}-\mathrm{THF}$ synthesis reactions. The lowest values of $\mathrm{CEF}$ were obtained for reactions, related to the synthesis and output of taurine (CDO, SADC, HTD, Taur_out) 


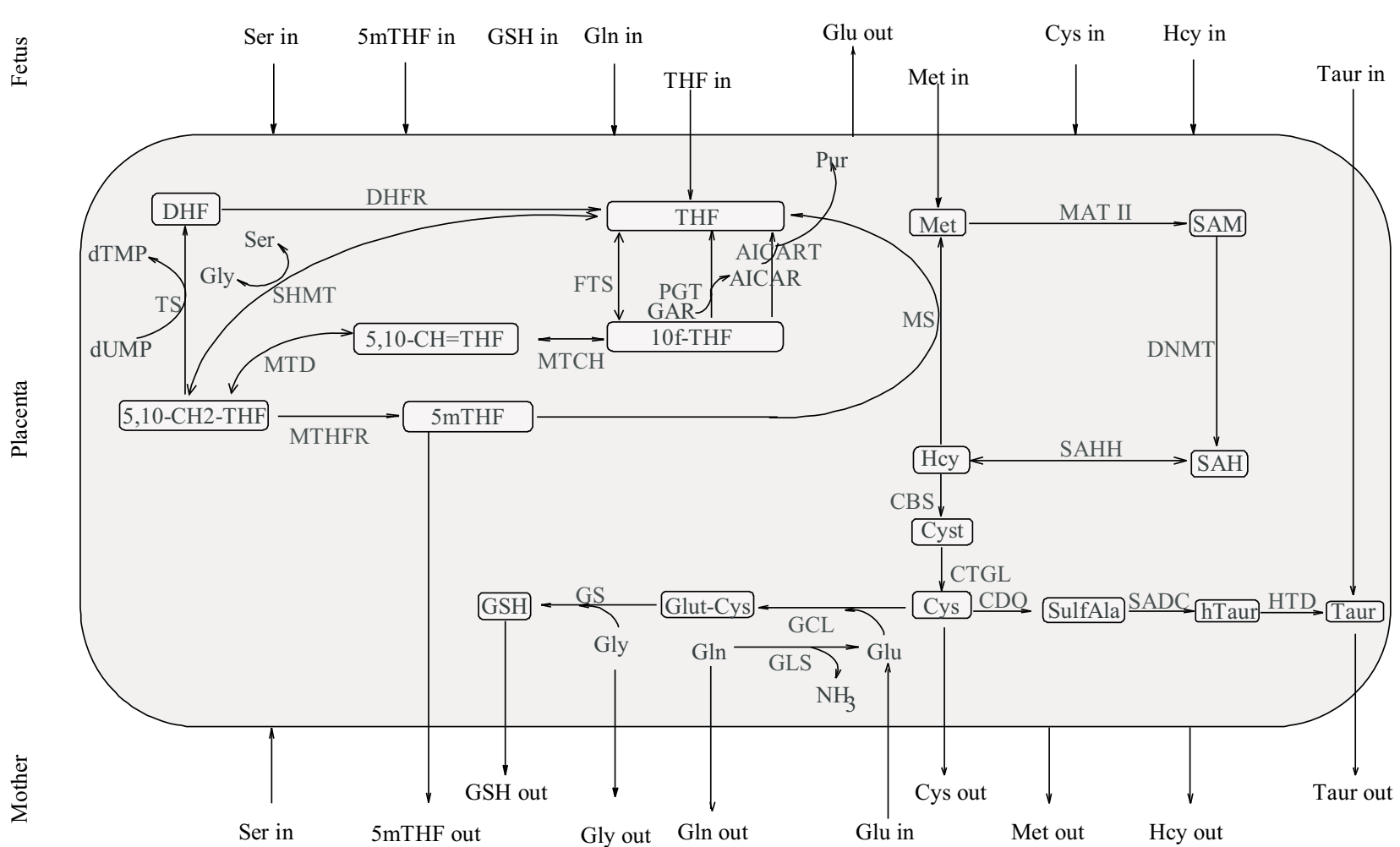

Fig. 1. The metabolic network of the folate-dependent processes in placenta. Enzymes: AICAR - 5-aminoimidazole-4-carboxamide-ribotide; AICART - phosphoribosyl aminoimidazole carboxamide formyltransferase; CBS - cystathionine beta-synthase; CDO - cysteine dioxygenase; CTGL - cystathionine-gamma-lyase; DHFR - dihydrofolate reductase; DNMT - DNA-methyltransferase; FTS - formyltetrahydrofolate synthetase; GCL - glutamate cysteine ligase; GLS - glutaminase; GLUD - glutamate dehydrogenase; GNMT - glycine-N-methyltransferase; GS glutathione synthetase; HTD - hypotaurine dehydrogenase; MAT - methionine adenosyltransferase; MS - methionine synthetase; MTCH methenyltetrahydrofolate cyclohydrolase; MTD - methylenetetrahydrofolate dehydrogenase; MTHFR - methylenetetrahydrofolate reductase; PGT - phosphoribosyl formyltransferase; SADC - cysteine sulfamoyl acid decarboxylase; SAHH - S-adenosyltransferase; SHMT - serine methyltransferase; TS - thymidine synthase. Metabolites: 10-f-THF - 10-formyltetrahydrofolate; 5,10- $\mathrm{CH}=\mathrm{THF}-5,10$ - methenyltetrahydrofolate; 5,10- $\mathrm{CH}_{2}$ - THF - 5,10-methylenetetrahydrofolate; 5MTHF - 5-methyltetrahydrofolate; Cys - cysteine; Cyst - cystathionine; DHF - dihydrofolate; dTMP - deoxythymidine monophosphate; dUmp - deoxyadenosine monophosphate; GAR - glycinamide ribonucleotide; Glu - glutamic acid; GlutCys - glutamyl cysteine; Gly - glycine; GSH - glutathione; Hcy - homocysteine; SAM - S-adenosylmethionine; SAH - S-adenosylhomocysteine; Ser - serine; THF - tetrahydrofolate; Met - methionine

as well as the fluxes of input/output of some metabolites: Hcy_out, Fol_in, Taur_in, Gln_out (Addendum 5).

$C E F$ in the simulation conditions. The mutations of the MTHFR gene have been studied the most extensively. Almost $50 \%$ of the Caucasian population in Europe have the polymorphism of MTHFR gene in position 677 [18]. The homozygotes of T677T retain only $30 \%$ of the activity, whereas the heterozygotes retain $65 \%$ relative to the wild type [19]. MTHFR is the only enzyme, capable of synthesizing 5MTHF, which is the donor of the methyl group for the methionine cycle, therefore even its partial inactivation has a considerable effect on the work of the whole network. The decrease in the activity of MTHFR affects not only 5MTHF synthesis and Hcy remethylation, but also the glutathione synthesis and methylation processes. Fig. 2 presents the dependence of CEF change on the inactivation degree for this enzyme.

In Fig. 2 it is evident that the 0.5 inactivation degree of the enzyme is a «breaking point, prior to which the network is still attempting to «cope with» the increased number of Hcy, gradually increasing the fluxes via the reactions of its elimination - the reactions of synthesis and removal of Cys and Taur, and the fluxes of 5MTHF input for the Hcy remethylation processes. The reduction of fluxes via the reactions of the methionine cycle is gradual. In case of the MTHFR inactivation over 0.5, the Hcy output flux, the 5MTHF input flux, the synthesis reaction fluxes (CDO, SADC, HTD), and the removal of Cys and Taur reach the plateau. Therewith the 


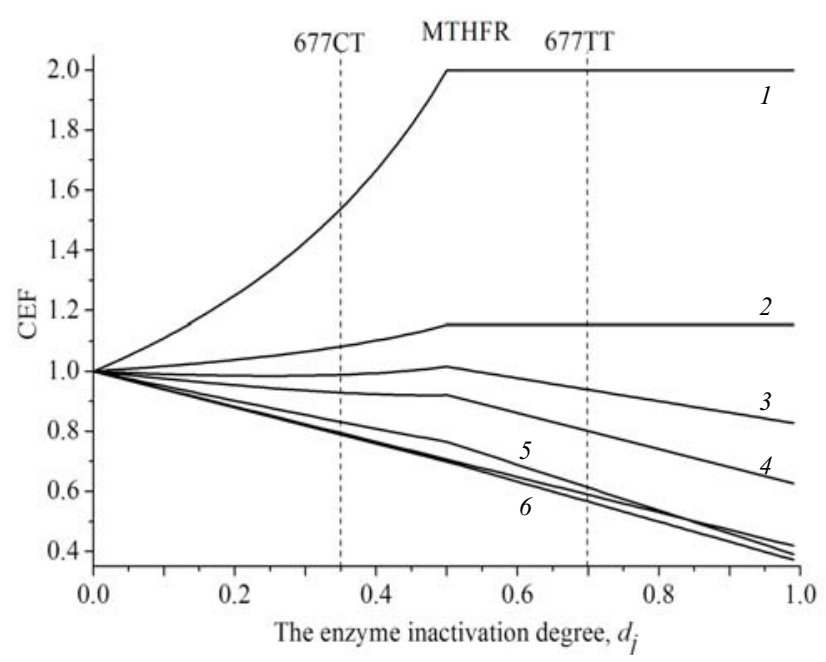

Fig. 2. The change of control-effective fluxes (CEF) depending on the inactivation degree of MTHFR enzyme: 1 - Hcy input flux, 5MTHF output flux; 2 - Taur, Cys output flux, CDO, SADC, HTD; 3 - Met input flux; 4 - the methionine cycle reactions; 5 -MS; 6 - THF input flux and Met, 5MTHF output flux. $Y$-axis contains CEF, scaled to the same index with a completely functional enzyme; $X$-axis reads as follows: 0 a completely functional enzyme; 1 - complete inactivation of the enzyme. The change of CEF was introduced in the figure for the most relevant reactions

fluxes via the reactions of the methionine cycle and Met input are reduced as well.

For instance, $30 \%$ activity of MTHFR (677TT genotype, 0.7 inactivation degree) leads to the reduction of the flux via the reactions of the methionine cycle by $20 \%$, via MS - by $40 \%$, the reduction of the Met input flux by $7 \%$ with the increase in the flux of output Hcy and input $5 \mathrm{MTHF}$ by $100 \%$ and the output fluxes of Cys and Taur - by $14 \%$. This correlation of fluxes in the placental tissue facilitates the Hcy accumulation. The change in MTHFR activity does not reflect on the CEF of folate cycle fluxes - FTS, MTCH, MTD, DHFR.

The results of calculations are in agreement with the scientific literature data. In the clinical practice the carriage of MTHFR mutant forms in human placenta prevails in case of a complicated pregnancy and is related to the reduction in Hcy remethylation in favor of the synthesis of nucleotides [20-22]. The simulation results demonstrate that the presence of MTHFR mutant forms leads to a considerable reduction in the flux via the reaction, catalyzed by MS, due to the reduction in 5MTHF production. The decreased intake of the folic acid and group B vitamins (coenzymes for MS and CBS) with food may lead to the failure of the compensation processes and the development of homocysteinemia.

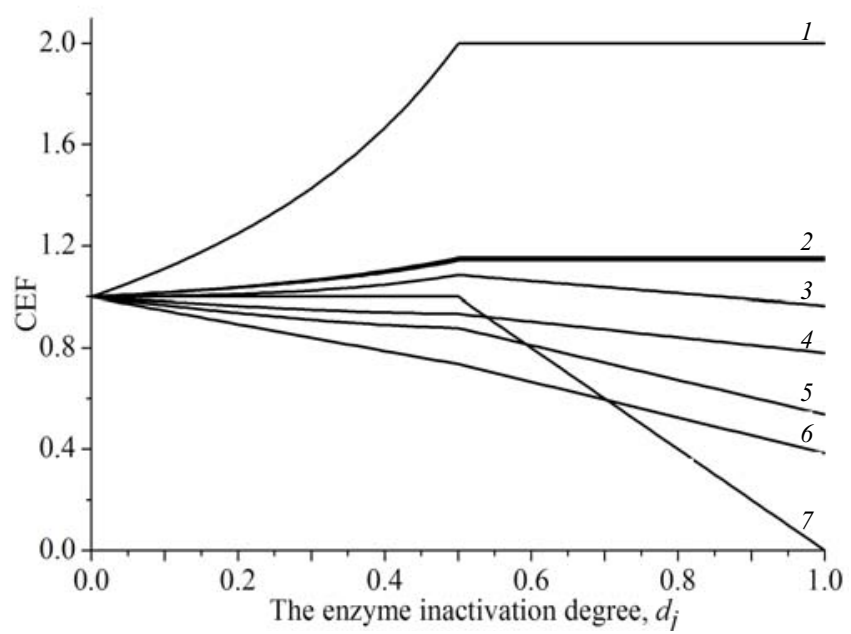

Fig. 3. The change of control-effective fluxes (CEF) depending on the inactivation degree of MS enzyme: 1 - Hcy input flux; 2 - Taur, Cys output flux, Taur synthesis reactions; 3 - Met input flux; 4 - the transsulfuration reactions; 5 - the methionine cycle reactions; 6 -MTHFR; 7 - 5MTHF input flux. $Y$-axis contains CEF, scaled to the same index with a completely functional enzyme; $X$-axis reads as follows: 0 - a completely functional enzyme; 1 - complete inactivation of the enzyme. The change of CEF was introduced in the figure for the most relevant reactions

Therefore, it was the first simulated behavior of all the FDP reactions in conditions of reduced MTHFR activity which promoted a better understanding of the logics of the system functioning. The MS-catalyzed reactions as well as the Hcy output and the 5MTHFR input demonstrated the highest sensitivity to the change in the MTHFR activity. The reduction of the flux via the Hcy remethylation reaction and the disproportional increase in the transsulfuration promote the Hcy accumulation in the system.

Another vital enzyme in the FDP network is the vitamin $\mathrm{B}_{12}$-dependent MS. There are over 13 mutations of the $M S$ gene [23], which, depending on their localization, may lead to the decrease in the enzyme activity. Three metabolic pathways cross in MS: the exchange of folates, vitamin $\mathrm{B}_{12}$ and sulfur-containing aminoacids. Therefore the decreased activity of this enzyme will result in the decreased or completely absent synthesis of methylcobalamin (one of the vitamin $B_{12}$ forms), hyperhomocysteinemia and hypomethioninemia [24].

Fig. 3 presents the dependence of CEF change on the inactivation degree of the enzyme. According to the obtained data, the MS deficiency leads to a sharp decline in the 5MTHF flux, coming from outside. There is also a sharp reduction in the 5MTHF production in the 


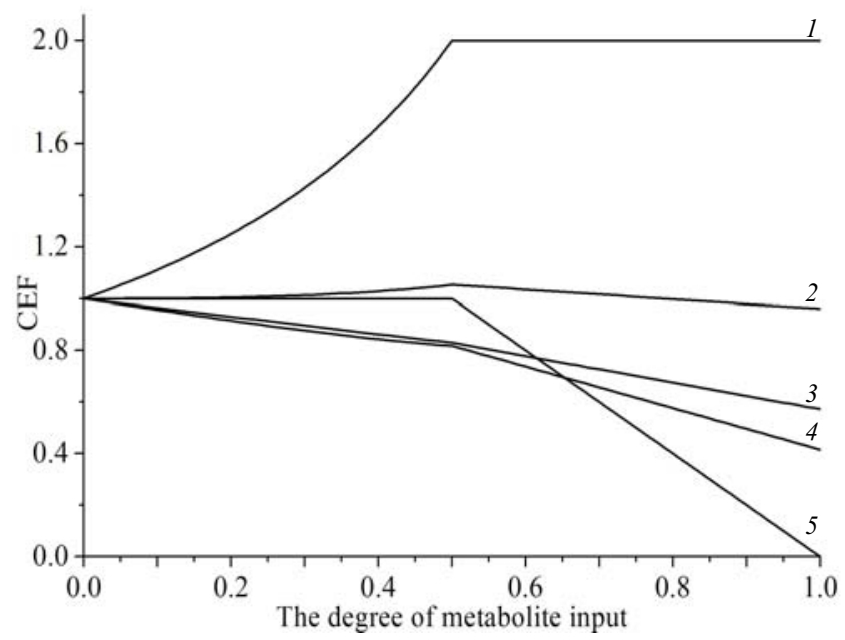

Fig. 4. The change of control-effective fluxes (CEF) depending on the Met input into the system: 1 -5MTHF input flux; $2-\mathrm{MS} ; 3$ - the transsulfuration reactions; 4 - the methionine cycle reactions; 5 - Hcy output flux. $Y$-axis contains CEF, scaled to the same index in the norm; $X$-axis reads as follows: 1 - normal input; 0 - the metabolite is not transported. The change of CEF was introduced in the figure for the most relevant reactions

MTHFR-catalyzed reaction. The flux via the methionine cycle decreases. The flux via the reactions of transsulfuration and the taurine synthesis increases by $15 \%$. There is a significant, up to two-fold increase in the flux of output Hcy.

Therefore, the increase in the output Hcy flux and an insufficient increase in the fluxes via the main ways of its utilization will result in its accumulation in the system.

In this case the increased consumption of folates will not result in the normalization of the Hcy level in the plasma, as MS is the only enzyme, capable of metabolizing 5MTHF. The relevance of the normal work of the methionine cycle, MS in particular, for the fetal development is proven by the data of Swanson et al., according to which the homozygous MS-deficient mice had high embryonic mortality, regardless of the high content of folates in the diet, whereas the heterozygotes had the increased Hcy level [25].

As for humans, the defects in $M S$ gene lead to methylcobalamin deficiency G (cblG) [MIM:250940], also known as homocystinuriamegaloblastic anemia, G complementation type [26]. Less apparent MS activity deficiency may be associated with moderate hyperhomocysteinemia, be a risk factor for the fetal neural tube defects [27] and other pathologies of the cardiovascular and nervous systems.

Due to the relevance of the MS enzyme for the Hcy utilization, it is reasonable to prescribe vitamin $B_{12}$ to pregnant women as it is the cofactor for MS [28].

The diets with poor Met level also affect the redistribution of fluxes in the FDP system (Fig. 4). There is a sharply growing need of 5MTHF, but the flux via the MS reaction is increasing insignificantly (up to 5\%) and the activity of the methionine cycle processes is decreased not much $(<10 \%)$. The Hcy level remains stable for still some time. The increase in the Met deficiency (less than a half of the initial state) leads to the decrease in the fluxes via the methionine cycle reactions, the transsulfuration reactions and the output Hcy flux is also greatly decreased.

The low Met concentration in the plasma will promote the prevalent Hcy remethylation [29]. The trials involving volunteers demonstrated contradicting results: both increased Hcy concentration in people who followed a vegetarian diet or a diet with decreased Met consumption [30,31] and the absence of this dependence [29]. The vegetarians had the increased content of folates in the plasma along with the low content of vitamin $\mathrm{B}_{12}$, which may lead to MS deficiency and the increase in the Hcy concentration [30].

Conclusions. The elaborated stoichiometry model of FDPs in human placenta has been applied for the analysis of the system behavior in conditions of the decreased activity of MTHFR and MS as well as the input of Met into the system. The model utilizes the literature data and may be used to investigate the FDP network functioning and to predict its behavior in previously unstudied situations.

It has been demonstrated that the decrease in the MTHFR activity triggers the imbalance in the FDP network in human placenta, increases the 5MTHF consumption and promotes the Hcy accumulation. The results demonstrate that the reduction of fluxes via the main pathways of Hcy elimination (MS, the methionine cycle reactions, the reactions of cysteine and taurine synthesis) leads to its accumulation in the system. In addition, we have shown the effect of the decreased MTHFR activity on the processes of transsulfuration and Taur synthesis as well as the connection between MTHFR and MS - the decrease in the activity of one of them 
leads to the reduction of flux via the other, the deficiency of both promotes the accumulation of homocysteine.

The MS inactivation also has a considerable effect on the redistribution of fluxes in the network, especially on the pool of the folic acid, thus decreasing the $5 \mathrm{MTHF}$ consumption by the network and promoting the Hcy accumulation. Likewise the decrease in the MS activity affects directly related processes and also increases the synthesis and removal of Taur - an amino acid, required for the fetal development.

The insufficient consumption of Met leads to the increase in the 5MTHF consumption, the decrease in the Hcy content and the reduction of fluxes via the methionine cycle. The simulation results demonstrate relevant consequences of the Met consumption, which is half as large as the initial one.

The stoichiometry model has proven to be a convenient instrument in the research on how the change of different parts of the system affects the whole system. The simulation allows tracing the change of all the system components and their interrelations as well as estimating the change of which fluxes leads to the final results (the increase in the content of Hcy, Cys, Taur, the decrease in the content of folates), which are observed in the clinical practice. This fact testifies to the possibility of using this model to predict changes in the FDP system with different rates of the system com-ponents. The consideration of the content of folates, methionine and group B vitamins as a prerequisite of the functional activity of enzymes, and not merely the Hcy level as the main marker of FDP functioning, is required for the purposes of prescribing any well-grounded therapy.

Математичне моделювання фолат-залежних процесів у плаценті людини

\section{В. А. Доценко, М. Ю. Оболенська}

Резюме

Мета. Описати фолат-залежні прочеси в плащенті людини за допомогою стехіометричної моделі і дослідити поведінку системи за різних умов. Методи. Модель створено на основі стехіометріі реакиій фолат-залежних прочесів, що перебувають у стаціонарному стані, з використанням програми CellNetAnalyzer. Поведінку системи охарактеризовано через елементарні моди і коефіиієнти контролю за потоками залежно від активності метилентетрагідрофолат-редуктази і метіонінсинтази і надходження метіоніну. Результати. Зміна активності метилентетрагідрофолат-редуктази спричиняє зниження потоків через основні шляхи елімінації гомоцистеїну та збільшення потреби у 5-метилтетра- гідрофолаті. Інактивація метіонінсинтази зменшує споживання 5-метилтетрагідрофолату $і$ збільшує потоки через реакції синтезу таурину. Брак метіоніну призводить до зростання споживання 5-метилтетрагідрофолату, зменшення вмісту гомоцистейну та зниження потоків через реакиії метіонінового цһиклу. Висновки. Аналіз функиіонування моделі виявив відповідність змін у функціонуванні системи клінічним показникам. Але є свідоцтва того, щио рівень гомоцистейну як маркера функціонування фолатзалежних прочесів є недостатнім для призначення обгрунтованої терапї.

Ключові слова: фолат-залежні процеси, стехіометрична модель, елементарна мода, коефіцієнти контролю за потоками.

Математическое моделирование фолат-зависимых процессов в плаценте человека

\section{В. А. Доценко, М. Ю. Оболенская}

Резюме

Цель. Описать фолат-зависимые прочессы в плаценте человека с помощью стехиометрической модели и исследовать поведение системы в различных условиях. Методы. Модель создана на основе стехиометрии реакиий фолат-зависимых процессов, находящихся в стационарном состоянии, с использованием программы CellNetAnalyzer. Поведение системы охарактеризовано с применением элементарных мод и коэффициентов контроля за потоками в зависимости от активности метилентетрагидрофо-латредуктазы и метионинсинтазы и поступления метионина. Результаты. Изменение активности метилентетрагидрофолат-редуктазы вызывает снижение потоков через основные пути элиминации гомоцистеина и увеличивает потребность в 5-метилтетрагидрофолате. Инактивация метионинсинтазы уменьшает потребление 5-метилтетрагидрофолата и увеличивает потоки через реакции синтеза таурина. Недостаток метионина приводит к росту потребления 5-метилтетрагидрофолата, уменьшению содержания гомоцистеина и снижению потоков через реакцчии метионинового ичикла. Выводы. Анализ функционирования модели выявил соответствие изменений в функционировании системы клиническим показателям. Но есть свидетельства того, что уровень гомоцистеина как маркера функционирования фолатзависимых прочессов является недостаточным для назначения обоснованной терапии.

Ключевые слова: фолат-зависимые процессы, стехиометрическая модель, элементарная мода, коэффициент контроля за потоками.

\section{REFERENCES}

1. Mykytenko DO, Tymchenko OI. Prevalence of polymorphism of methylentetrahydropholatreductase gene among parturients of Kiev region. Medical Perspectives. 2009. 14(3):100-104.

2. Tymchenko OI, Lynchak OV, Mykytenko DO, Pol'ka OO, Pokanevych TM. Nervous system congenital pathology: the prevalence of nervous tube defects and possibilities of folic acid in prevention of its development. J. Pediatrics, Obstetrics and Gynecology. 2010; 72(1):18-24.

3. Kalhan SC, Marczewski SE. Methionine, homocysteine, one carbon metabolism and fetal growth. Rev Endocr Metab Disord. 2012; 13(2):109-19.

4. Martsenyuk OP, Obolenska MYu, Romanets KL, Huppertz B. Effect of homocysteine on the structure and functions of human placenta trophoblast. Ukr Biokhim Zh. 2009. 81(5):40-49. 
5. Nijhout HF, Reed MC, Budu P, Ulrich CM. A mathematical model of the folate cycle: new insights into folate homeostasis. $J$ Biol Chem. 2004; 279(53):55008-16.

6. Ulrich CM, Neuhouser M, Liu AY, Boynton A, Gregory JF 3rd, Shane B, James SJ, Reed MC, Nijhout HF. Mathematical modeling of folate metabolism: predicted effects of genetic polymorphisms on mechanisms and biomarkers relevant to carcinogenesis. Cancer Epidemiol Biomarkers Prev. 2008; 17(7):1822-31.

7. Finkelstein JD, Martin JJ, Harris BJ. Methionine metabolism in mammals. The methionine-sparing effect of cystine. J Biol Chem. 1988; 263(24):11750-4.

8. Tibbetts AS, Appling DR. Compartmentalization of Mammalian folate-mediated one-carbon metabolism. Annu Rev Nutr. 2010; 30:57-81.

9. Engel SM, Olshan AF, Siega-Riz AM, Savitz DA, Chanock SJ. Polymorphisms in folate metabolizing genes and risk for spontaneous preterm and small-for-gestational age birth. Am J Obstet Gynecol. 2006; 195(5):1231.e1-11.

10. Schuster S, Fell DA, Dandekar T. A general definition of metabolic pathways useful for systematic organization and analysis of complex metabolic networks. Nat Biotechnol. 2000;18(3): 326-32.

11. Gagneur J, Klamt $S$. Computation of elementary modes: a unifying framework and the new binary approach. BMC Bioinformatics. 2004; 5:175.

12. Cakir T, Tacer CS, Ulgen KO. Metabolic pathway analysis of enzyme-deficient human red blood cells. Biosystems. 2004;78 (1-3):49-67.

13. Stelling J, Klamt S, Bettenbrock K, Schuster S, Gilles ED. Metabolic network structure determines key aspects of functionality and regulation. Nature. 2002; 420(6912):190-3.

14. Obolenskaya MYu, Rodriges RR, Martsenyuk OP. Folate-related processes in human placenta: gene expression, aminothiols, proliferation and apoptosis. Ukr Biokhim Zh. 2011. 83(1): 5-17.

15. Rodriguez RR, Lushchyk IS, Obolenska MYu. Stoichiometric model of folate-dependent metabolism of one-carbon units in human placenta. Ukr Biokhim Zh. 2012; 84(4): 20-31.

16. Battaglia FC, Regnault TR. Placental transport and metabolism of amino acids. Placenta. 2001; 22(2-3): 145-61.

17. Sastre J, Pallardo FV, Vina J. Glutathione. The Handbook of Environmental Chemistry. Springer, 2005; Vol. 20: 91-108.

18. Gasparovic J, Raslova K, Basistova Z, Zacharova M, Wsolova L, Avdicova M, Blazicek P, Lietava J, Sivakova D. Effect of C677T methylenetetrahydrofolate reductase gene polymorphism on plasma homocysteine levels in ethnic groups. Physiol Res. 2004; 53(2):215-8.

19. Frosst P, Blom HJ, Milos R, Goyette P, Sheppard CA, Matthews $R G$, Boers GJ, den Heijer M, Kluijtmans LA, van den Heuvel $L P$, Rozen $R$. A candidate genetic risk factor for vascular disease: a common mutation in methylenetetrahydrofolate reductase. Nat Genet. 1995; 10(1): 111-3.
20. Martseniuk OP, Mishlanova Sh, Romanets' KL, Tepliuk NM, Obolens 'ka MYu. The level of low molecular thiols and folate in human placenta. Ukr Biokhim Zh. 2009; 81(4): 94-104.

21. Bailey LB, Gregory JF 3rd. Polymorphisms of methylenetetrahydrofolate reductase and other enzymes: metabolic significance, risks and impact on folate requirement. J Nutr. 1999; 129 (5):919-22.

22. Mislanova $C$, Martsenyuk O, Huppertz B, Obolenskaya M. Placental markers of folate-related metabolism in preeclampsia. Reproduction. 2011; 142(3):467-76.

23. Watkins D, Ru M, Hwang HY, Kim CD, Murray A, Philip NS, Kim $W$, Legakis H, Wai T, Hilton JF, Ge B, Dore C, Hosack A, Wilson A, Gravel RA, Shane B, Hudson TJ, Rosenblatt DS. Hyperhomocysteinemia due to methionine synthase deficiency, cblG: structure of the MTR gene, genotype diversity, and recognition of a common mutation, P1173L. Am J Hum Genet. 2002;71(1):143-53.

24. Rosenblatt D, Fenton $W$. The metabolic and molecular bases of inherited disease. New York: McGraw-Hill, 2001; 3933 p.

25. Swanson DA, Liu ML, Baker PJ, Garrett L, Stitzel M, Wu J, Harris M, Banerjee R, Shane B, Brody LC. Targeted disruption of the methionine synthase gene in mice. Mol Cell Biol. 2001; 21(4):1058-65.

26. Gulati S, Baker P, Li YN, Fowler B, Kruger W, Brody LC, Banerjee $R$. Defects in human methionine synthase in cblG patients. Hum Mol Genet. 1996; 5(12):1859-65.

27. O'Leary VB, Mills JL, Pangilinan F, Kirke PN, Cox C, Conley M, Weiler A, Peng K, Shane B, Scott JM, Parle-McDermott A, Molloy AM, Brody LC; Members of the Birth Defects Research Group. Analysis of methionine synthase reductase polymorphisms for neural tube defects risk association. Mol Genet Metab. 2005; 85 (3):220-7.

28. Mykytenko DO, Tymchenko OI, Mykytenko OP. Association of methlylentetrahydrofolate reductase polymorphisms with pathology of pregnant and fetus at the kyiv region. Collection of $\mathrm{sci}$ entific works of staff members of NMAPE named after P. L. Shupyk. 2009; 18(4): 21-31.

29. Huang YC, Chang SJ, Chiu YT, Chang HH, Cheng CH. The status of plasma homocysteine and related B-vitamins in healthy young vegetarians and nonvegetarians. Eur J Nutr. 2003; 42(2): 84-90.

30. Hung CJ, Huang PC, Lu SC, Li YH, Huang HB, Lin BF, Chang $S J$, Chou HF. Plasma homocysteine levels in Taiwanese vegetarians are higher than those of omnivores. J Nutr. 2002; 132(2): $152-8$.

31. Mann NJ, Li D, Sinclair AJ, Dudman NP, Guo XW, Elsworth GR, Wilson AK, Kelly FD. The effect of diet on plasma homocysteine concentrations in healthy male subjects. Eur J Clin Nutr. 1999; 53(11):895-9. 